\title{
Penampil Gelombang Tegangan dan Arus Berbasis Arduino Due untuk Generator AC Tiga Fasa
}

\section{MARTANTO ${ }^{1}$, RB DWISENO WIHADI $^{2}$, RONNY DWI AGUSULISTYO ${ }^{3}$, TJENDRO 4}

1,4 Teknik Elektro, Universitas Sanata Dharma, Yogyakarta

${ }^{2}$ Teknik Mesin, Universitas Sanata Dharma, Yogyakarta

3 Politeknik Mekatronika Sanata Dharma, Yogyakarta

Email: martanto@usd.ac.id

Received 30 Desember 2019| Revised 3 Februari 2020| Accepted 29 Maret 2020

\begin{abstract}
ABSTRAK
Dalam pengembangan generator tiga fasa magnet permanen diperlukan pengukuran besaran-besaran untuk melihat karakteristik generator. Besaran yang biasanya diukur adalah tegangan, arus, dan daya, namun bentuk gelombang keluaran tegangan dan arus tiap fasa kurang diperhatikan apakah sinus atau tidak. Maka perlu dirancang sebuah sistem yang bisa menampilkan bentuk gelombang tegangan dan arus sekaligus. Sistem ini diimplementasikan menggunakan sensor tegangan, sensor arus, rangkaian pengondisi sinyal, Arduino Due, dan komputer sebagai penampil menggunakan bahasa Python. Hasil pengujian diperoleh bahwa sistem bisa menampilkan bentuk gelombang keluaran tegangan dan arus, menampilkan nilai maksimum, minimum, rerata, dan rms. Nilai galat rata-rata untuk ketiga pengukuran tegangan adalah 1\%, dan untuk pengukuran arus adalah $3,15 \%$.
\end{abstract}

Kata kunci: gelombang tegangan dan arus, Arduino Due, Python, tiga fasa

\begin{abstract}
The development of three phase permanent magnet generators require the measurement of related quantities to determine the characteristics of generator. The common measured quantities are voltage, current, and power. However the voltage and current output waveforms of each phase are not considered. Therefore a system is designed which is able to display voltage and current waveforms at once. This system is implemented using a voltage sensor, current sensor, signal conditioning circuit, Arduino Due, and a computer as a GUI using the Python programming language. The results of implementation and testing show that the GUI is able to display the voltage and current output waveforms, in addition, performs the maximum, minimum, average, and rms values. The average error value for the three voltage measurements is $1 \%$, and for the three current measurements is $3.15 \%$.
\end{abstract}

Keywords: voltage and current waveforms, Arduino Due, Python, three phases 


\section{PENDAHULUAN}

Generator merupakan komponen vital dalam pengembangan sistem pembangkitan energi listrik. Sistem energi alternatif skala kecil membutuhkan generator yang berukuran kecil, handal, dapat dirawat dengan mudah dan merupakan generator putaran rendah. Di dalam pengembangan generator tiga fasa putaran rendah ada kebutuhan pengukuran untuk mengetahui karakteristik generator. Beberapa penelitian terkait pengembangan generator, pengukuran dilakukan untuk mengetahui tegangan, arus dan daya yang dihasilkan. Hari Prasetijo dkk (Prasetijo, dkk, 2012) dalam makalah Generator Magnet Permanen Sebagai Pembangkit Listrik Putaran Rendah, di dalam metoda pengujian generator yang dikembangkan adalah dengan menganalisa tegangan output generator, frekuensi dan daya keluaran. Tidak disebutkan cara pengukuran tegangan generator yang akan dianalisis. Dan tidak disertakan gambar bentuk gelombang keluaran genertor. Dalam penelitian Perancangan Prototype Generator Magnet Permanen 1 Fasa Jenis Fluks Aksial pada Putaran Rendah oleh Leo Noprizal (Noprizal, 2016) dilakukan pengukuran tegangan, arus, frekuensi dan putaran poros, tidak ditampilkan bentuk gelombang keluaran generator. Dalam penelitian Perancangan Generator Magnet Permanen dengan Arah Fluks Aksial untuk Aplikasi Pembangkit Listrik oleh Ardhians Abdillah Wijaya (Abdillah, 2016), yang membuat generator tiga fasa, dalam pengujian keluaran generator telah disampaikan bentuk gelmbangnya, tetapi hanya untuk satu fasa saja, dengan menggunakan osiloskop. Tidak ditunjukkan bentuk gelombang untuk fasa yang lain.

Pengukuran bentuk gelombang berguna untuk mengetahui parameter-paremater gelombang, amplitudo, pergeseran sudut fasa antar fasa, dan frekuensi gelombang. Untuk menampilkan gelombang bisa menggunakan osiloskop, yang kebanyakan osiloskop ada dua kanal pengukuran tegangan. Jika akan melihat bentuk gelombang arus maka harus ditambahkan piranti yang lain. Beberapa penelitian terkait penampil gelombang sudah dilakukan. Dalam penelitian Arduino Based Real-Time Oscilloscope oleh Odunlade Emmanuel, menggunakan mikrokontroler Arduino Uno, dengan penampil menggunakan GUI yang dibangun menggunakan python, hanya satu kanal gelombang yang ditampilkan (Emmanuel, 2018). Dalam penelitian $A$ low cost portable oscilloscope based on Arduino and GLCD' oleh Ishtiak Ahmed Karim menggunakan layar GLCD (Graphical Liquid Crystal Display) sebagai unit penampil, ada dua kanal bentuk gelombang yang bisa ditampilkan (Karim, 2014). Dari beberapa implementasi penampil gelombang tersebut belum dibuat untuk menampilkan bentuk gelombang tegangan dan arus sekaligus.

Penelitian ini bertujuan membuat sistem penampil bentuk gelombang tegangan dan arus untuk generator tiga fasa. Sistem ini diperlukan terutama untuk mengetahui bentuk gelombang tegangan dari setiap fasa apakah sinusoidal atau tidak, dan untuk mengetahui keseimbangan pergeseran sudut fasa. Sistem terdiri atas sensor tegangan, sensor arus, rangkaian pengondisi sinyal, mikrokontroler dalam papan Arduino Due, dan program penampil (Graphical User Interface - GUI) dalam komputer yang digunakan untuk menampilkan gelombang tegangan keluaran generator setiap fasa dan gelombang arus setiap fasa sekaligus. Digunakannya Arduino Due terutama karena memiliki memori flash yang cukup besar yaitu $512 \mathrm{kbyte}$, dan resolusi ADC (Analog to Digital Converter) 12bit (Arduino, 2017). Untuk membuat GUI digunakan bahasa pemrograman Python 2.7. Bahasa python dipilih karena merupakan bahasa pemrograman yang tidak berbayar (Willems, 2017), dan mudah dipelajari (Kuchling, 2010). Spesifikasi rancangan pengukuran dibatasi untuk jangkauan tegangan sebesar - $30 \mathrm{~V}$ sampai dengan $30 \mathrm{~V}$, sedangkan untuk arus adalah $-5 \mathrm{~A}$ sampai $5 \mathrm{~A}$. 
Martanto, dkk

\section{METODE PENELITIAN}

Proses tahapan penelitian ini adalah sebagai berikut: pertama menentukan spesisikasi sistem, kemudian melakukan perancangan sistem yang terdiri dari perancangan perangkat keras dan perangkat lunak. Selanjutnya mengimplementasi sistem, dan pengujian sistem hasil implementasi untuk mengetahui keberhasilan sistem yang dirancang, lalu dilakukan pembahasan dan pengambilan kesimpulan. Gambar 1 menunjukkan diagram kotak sistem penampil gelombang tegangan dan arus tiga fasa yang dirancang.

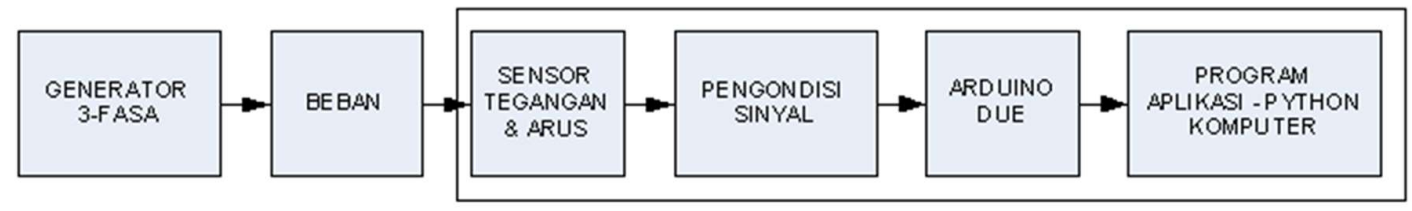

Gambar 1. Diagram Kotak Sistem Penampil Gelombang Tegangan dan Arus Tiga Fasa

Berdasarkan Gambar 1, keluaran generator tiga fasa dihubungkan ke beban, setiap fasa akan dilihat bentuk gelombang tegangan dan arus yang mengalir ke beban. Terdapat tiga sensor pengukur tegangan dan tiga sensor untuk pengukur arus. Untuk penyesuaian level tegangan antara tegangan keluaran sensor dengan masukan pin ADC digunakan rangkaian pengondisi sinyal. Setiap keluaran pengondisi sinyal tegangan dan keluaran pengondisi sinyal arus kemudian dihubungkan ke port masukan ADC Arduino Due, yaitu dari ADC0 sampai ADC5. Kemudian Arduino Due mengirimkan data ke komputer melalui komunikasi serial. Komputer kemudian menampilkan data tersebut ke dalam bentuk gelombang. Dalam sistem ini pengukuran tegangan dibatasi untuk jangkauan tegangan masukan sebesar -30V sampai $+30 \mathrm{~V}$. Pengukuran arus dibatasi untuk pengukuran arus sebesar $-5 \mathrm{~A}$ sampai $+5 \mathrm{~A}$.

Pengondisi sinyal yang dibuat ada dua macam, yaitu pengondisi sinyal untuk pengukuran tegangan dan pengondisi sinyal untuk pengukuran arus. Rangkaian pengondisi sinyal yang dirancang menggunakan penguat operasional (opamp) catuan tunggal yaitu LM358. Tegangan catu daya yang digunakan sebesar $5 \mathrm{~V}$ diambil dari sumber tegangan yang tersedia pada pin Arduino Due. Tegangan masukan ke port ADC maksimal sebesar 3,3V. Batasan tegangan yang akan diukur adalah mulai dari -30V sampai +30V. Tegangan keluaran LM358 minimal sebesar OV hingga maksimal 3,5V (Texas Instruments, 2019). Pengondisi sinyal tegangan dibuat dengan ketentuan: saat tegangan masukan sebesar -30V tegangan keluaran pengondisi sinyal ditentukan sebesar $0,1 \mathrm{~V}$, dan saat tegangan masukan sebesar $+30 \mathrm{~V}$ tegangan keluaran ditentukan sebesar 2,3V. Berdasar ketentuan ini dapat dibuat persamaan pengondisi sinyal yang ditunjukkan pada Persamaan (1).

$$
y=0,025 x+1,55
$$

dengan $x$ menyatakan tegangan masukan, dan $y$ adalah tegangan keluaran pengondisi sinyal. Persamaan ini diimplementasikan ke dalam rangkaian seperti Gambar 2, dibuat sebanyak 3 buah rangkaian yang sama untuk pengukuran tegangan. Rangkaian yang digunakan mengacu pada dokumen cara mendesain rangkaian opamp dengan catu tunggal (Carter, 2016). Persamaan keluaran opamp pertama ditunjukkan oleh Persamaan (2).

$$
V_{b}=-\frac{R_{2}}{R_{1}} V_{i n}+\left(\frac{R_{2}}{R_{1}}+1\right) V_{a}
$$

Dengan $V a$ adalah tegangan pada $R_{4}$ seperti Persamaan (3) 


$$
V_{a}=-\frac{R_{4}}{R_{4}+R_{3}} V_{c c}
$$

Vcc adalah tegangan catu daya. Sedangkan persamaan keluaran opamp kedua ditunjukkan pada Persamaan (4).

$$
V_{\text {out }}=-\frac{R_{6}}{R_{5}} V_{b}+\left(\frac{R_{6}}{R_{5}}+1\right) V_{c}
$$

dengan $V_{c}$ adalah tegangan pada $R_{\mathcal{B}_{1}}$ merupakan hasil pembagi tegangan tegangan sumber Vcc oleh resistor R7 dan R8. Vb adalah tegangan keluaran opamp pertama. Kedua opamp diimplementasikan menggunakan satu buah LM358. Nilai komponen resistor dipilih agar dapat memenuhi Persamaan (1).

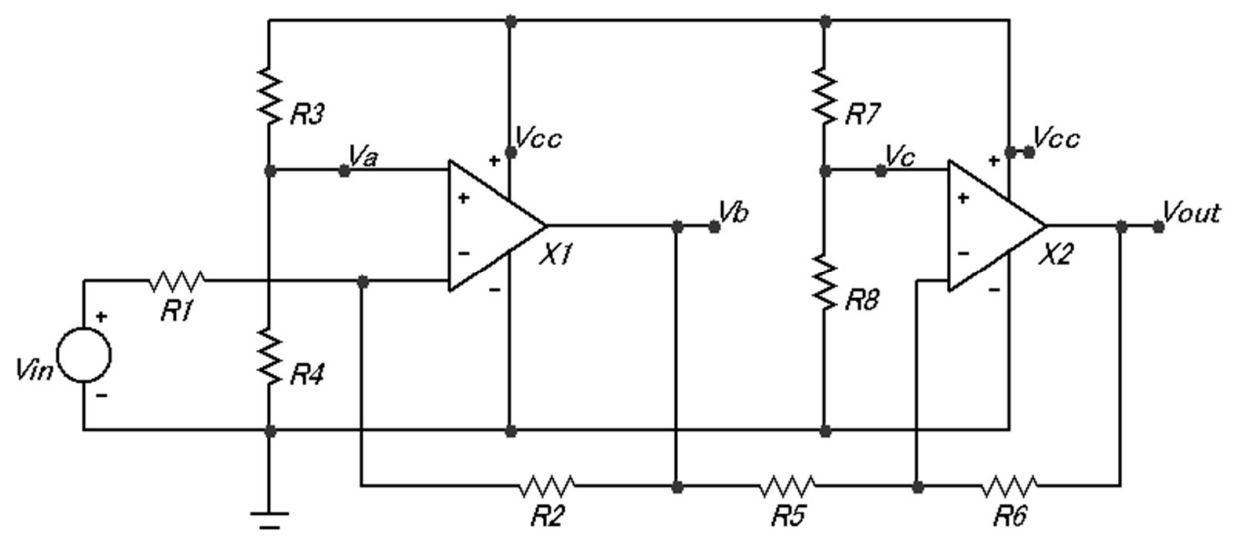

Gambar 2. Rangkaian Pengondisi Sinyal

Sensor arus yang digunakan adalah ACS712-05 yang memiliki batasan kemampuan pengukuran sampai 5A, tegangan catu yang digunakan sebesar 5V. Sensitifitas tipikal ACS71205 adalah 185mV/A (Allegro, 2019). Dengan menggunakan nilai sensitifitas tipikalnya, saat arus mengalir sebesar 5A maka tegangan keluaran ACS712-05 adalah 3,45V, dan saat tidak ada arus tegangan keluarannya sebesar $2,5 \mathrm{~V}$, serta saat ada arus $-5 \mathrm{~A}$ tegangan keluarannya sebesar 1,55V. Pengondisi sinyal arus dirancang dengan ketentuan: saat tegangan sensor sebesar 3,45V keluaran pengondisi sinyal sebesar 2,1V, dan saat tegangan sensor sebesar $1,55 \mathrm{~V}$ keluaran pengondisi sinyal sebesar $1,1 \mathrm{~V}$. Persamaan pengondisi sinyal pengukuran arus ditunjukkan pada Persamaan (5).

$$
\mathrm{y}=0,5405 \mathrm{x}+0,2486
$$

dengan $x$ adalah tegangan keluaran sensor arus dan $y$ adalah tegangan keluaran pengondisi sinyal. Rangkaian pengondisi sinyal pengukuran arus yang digunakan seperti rangkaian pengondisi sinyal tegangan, yang berbeda adalah nilai komponen resistor yang digunakan, dan dibuat sebanyak 3 buah rangkaian yang sama untuk pengukuran arus.

Setiap keluaran rangkaian pengondisi sinyal selanjutnya dihubungkan ke masukan ADC Arduino Due. Arduino Due memiliki sebanyak 12 jalur ADC yang bisa digunakan (Arduino, 2017). Untuk pengukuran tegangan digunakan port $A D C 0, A D C 1$, dan $A D C 2$. Sedangkan untuk pengukuran arus digunakan port ADC3, ADC4 dan ADC5. Tahap selanjutnya adalah membuat program aplikasi pada mikrokontroler Arduino Due menggunakan Arduino IDE. Program aplikasi dirancang agar mikrokontroler melakukan pengkonversian data analog ke 
digital setiap port ADC, untuk kemudian dikirimkan ke komputer melalui komunikasi serial. Oleh komputer data ini akan diproses dan ditampilkan dalam bentuk plot gelombang serta dilakukan perhitungan nilai rerata, nilai maksimum, nilai minimum dan nilai $\mathrm{rms}$ (root mean square) dari data masukan.

Program pada mikrokontroler pertama-tama dilakukan pendeklarasian semua variabel yang diperlukan dan tipe data yang digunakan. Setiap sinyal dilakukan pembacaan pencuplikan sebanyak 200. Untuk itu setiap data pengukuran hasil konversi ADC disimpan dalam sebuah buffer dengan panjang buffer sebesar 200, dengan tipe data unsigned int. Untuk menyimpan data ini diperlukan sebanyak 4800 byte, satu data dengan tipe data unsigned int pada Arduino Due memerlukan 4 byte (Arduino, 2019). Pada bagian setup dilakukan inisialisasi pengaturan port komunikasi serial dan inisialisasi ADC. Nilai baudrate untuk komunikasi serial dibuat sebesar 38400. Resolusi ADC untuk konversi dibuat sebesar 12-bit. Pengaturan resolusi ADC menggunakan fungsi analogReadResolution(12) (Arduino, 2019). Nilai tegangan referensi ADC dibuat sama dengan 3,3V. Resolusi ADC 12-bit dan tegangan referensi 3,3V akan diperoleh sensitifitas sebesar $0,806 \mathrm{mV} /$ bit. Pada bagian loop dilakukan pembacaan data analog dari semua masukan ADC, berturut-turut mulai ADC0 sampai ADC5, lalu data disimpan dalam buffer data ADC, kemudian diberikan tunda untuk pengaturan waktu pencuplikan. Proses ini diulang kembali untuk pembacaaan sampai dengan 200 kali. Pengaturan waktu pencuplikan ditentukan berdasarkan jangkauan kerja frekuensi gelombang yang akan diamati, dalam hal ini ditetapkan sebesar $250 \mu s$.

Setelah proses pencuplikan sejumlah $6 \times 200$ data, lalu data dikirimkan ke komputer melalui komunikasi serial. Namun sebelum dilakukan pengiriman, dilakukan proses manipulasi data agar data yang dikirim ke komputer merupakan data yang baku untuk pengukuran tegangan dan pengukuran arus. Sebelum pembuatan program lebih lanjut, telah dilakukan pengujian untuk memperoleh karakteristik pengondisi sinyal dan konversi ADC untuk keenam pengondisi sinyal. Hasil untuk pengukuran tegangan dinyatakan dengan persamaan pada Tabel 1 nomor $1-3$, dengan $y$ adalah nilai keluaran ADC dan $x$ adalah nilai tegangan masukan pengondisi sinyal yang diukur. Hasil untuk pengukuran arus ditunjukkan oleh persamaan pada Tabel 1 nomor $4-6$, dengan $y$ adalah nilai keluaran ADC dan $x$ adalah nilai arus yang diukur.

Tabel 1. Persamaan Karakteristik Pengodisi Sinyal dan Konversi ADC Hasil Pengujian

\begin{tabular}{|c|c|c|}
\hline No & PengondisiSinyal & Persamaan \\
\hline 1 & Tegangan-I & $\mathrm{y}=30,196 \mathrm{x}+1887,4$ \\
\hline 2 & Tegangan-II & $\mathrm{y}=30,217 \mathrm{x}+1877,6$ \\
\hline 3 & Tegangan-III & $\mathrm{y}=30,005 \mathrm{x}+1875,6$ \\
\hline 4 & Arus-I & $\mathrm{y}=114,2175 \mathrm{x}+1857,4676$ \\
\hline 5 & Arus-II & $\mathrm{y}=116,5401 \mathrm{x}+1868,2622$ \\
\hline 6 & Arus-III & $\mathrm{y}=110,9645 \mathrm{x}+1857,4875$ \\
\hline
\end{tabular}

Untuk pengukuran tegangan nilai ADC dibuat sama dengan 32 kali tegangan masukan ditambah dengan 2000, jika tegangan yang diukur -30V maka diharapkan nilai ADC sama dengan 1040, saat masukan 30V nilai ADC sama dengan 2960. Untuk arus, nilai ADC sama dengan 200 kali arus ditambah 2000, jika arus masukan sama dengan 5A maka nilai ADC sama dengan 3000, dan jika arus sama dengan -5A maka nilai ADC sama dengan 1000 . Penyesuaian dalam program mikrokontroler didasarkan pada persamaan yang ada pada Tabel 2. 
Tabel 2. Persamaan Penyesuaian Program Mikrokontroler untuk Pengukuran Tegangan dan Arus

\begin{tabular}{|c|c|c|}
\hline No & Pengukuran & Persamaan \\
\hline 1 & Tegangan-I & $y=1,0594 x+0,4392$ \\
\hline 2 & Tegangan-II & $y=1,0587 x+12,1864$ \\
\hline 3 & Tegangan-III & $y=1,0661 x+0,4286$ \\
\hline 4 & Arus-I & $y=1,8020 x-1347,2642$ \\
\hline 5 & Arus-II & $y=1,7155 x-1204,9995$ \\
\hline 6 & Arus-III & $y=1,7506 x-1251,6574$ \\
\hline
\end{tabular}

Data yang dikirimkan dibuat dengan format tertentu. Satu paket data terdiri dari enam nilai hasil konversi ADC dari setiap pengukuran. Satu paket data diawali dengan tanda bintang $(*)$ dan diakhiri dengan tanda pagar (\#), urutan data yang dikirimkan adalah data indeks, data hasil adc ke-0, hingga adc ke-5, setiap informasi dipisahkan dengan koma (,). Nilai indeks menyatakan urutan paket data yang dikirimkan, mulai dari 0 sampai 199 atau 200 paket. Nilai indeks ini dipakai untuk proses pembuatan plot pada program aplikasi komputer.

Program aplikasi komputer dibuat menggunakan bahasa pemrograman Python 2.7. Beberapa modul tambahan yang dipakai adalah: modul Tkinter untuk membuat antarmuka (GUI), modul serial untuk komunikasi serial, modul math untuk perhitungan fungsi matematis, dan modul list_ports untuk mengetahui port serial yang sedang aktif. Program aplikasi pertama-tama memanggil modul-modul yang digunakan, inisialisasi variabel, konstanta berserta tipe datanya. Implementasi GUI terdiri atas beberapa Frame, Canvas, Scale, Button, OptionMenu dan Text. Untuk menampilkan plot gelombang digunakan Canvas dengan latar belakang gambar skala yang diambil dari berkas image. Digunakan 6 buah Scale untuk pengaturan posisi ofset arah vertikal, dan 6 buah Scale untuk pengaturan skala vertikal: V/div atau A/div, yang dilengkapi dengan nilai yang ditampilkan. Skala horisontal atau sumbu waktu tidak dilakukan pengaturan. Posisi sumbu waktu diatur berdasarkan nilai indeks paket data yang diterima komputer. Indeks bernilai 0 untuk posisi paling kiri, dan 199 untuk posisi paling kanan. Pemilihan port yang dipakai dan baudrate menggunakan OptionMenu.

Tombol fungsi perintah yang dipakai adalah: Set Baudrate, Set COM port, Open Port, Close Port, dan Clear. Tombol-tombol fungsi disediakan untuk mencari nilai: Max, Min, Avg, dan nilai Rms. Hasil perhitungan nilai-nilai ini ditampilkan dalam sebuah Text. Sebelum dipergunakan untuk pengukuran diberikan satu tombol yang berfungsi untuk penentuan nilai nol dengan memberikan masukan tegangan dan arus yang diukur sama dengan nol. Penggambaran bentuk gelombang menggunakan fungsi create_line() yang ada di dalam modul Canvas. Ukuran bidang gambar adalah 600 pixel x 600 pixel. Nilai data yang dikirimkan ke komputer adalah 1000 sampai 3000. Agar data ini dapat ditampilkan di dalam bidang gambar, dilakukan penyekalaan dan penyesuaian ofset.

\section{HASIL DAN ANALISIS}

Implementasi rangkaian pengondisi sinyal ditunjukkan pada Gambar 3(a). Rangkaian ini dihubungkan dengan papan Arduino Due. Terdapat 3 kabel masukan arus ('A') dihubungkan ke keluaran sensor arus, 3 kabel masukan lainnya ( $V$ ") dihubungkan ke tegangan yang akan diukur, dan 1 kabel untuk Ground. Catu daya 5V sensor arus dihubungkan dengan pin 5V pada papan Arduino. Konektor USB mikro pada papan Arduino dihubungkan ke komputer untuk jalur komunikasi serial dan pemberian catu daya papan Arduino. Pengujian dilakukan dengan cara memberikan tegagan masukan yang sudah diketahui (Vin) dan mengukur tegangan keluaran pengondisi sinyal (Vout). Tegangan untuk pengujian mulai dari -30V hingga 
$+30 \mathrm{~V}$. Hasil pengujian karakteristik ketiga pengondisi sinyal untuk pengukuran tegangan ditunjukkan pada Gambar 4a. Persamaan karakteristik ketiga pengindisi sinyal ditunjukkan pada Tabel 3 nomor 1-3. Terdapat perbedaan sensitifitas terhadap nilai perancangan berdasarkan Persamaan (1) diperoleh sebesar $1,6 \%$ dan kesalahan nilai ofset sebesar $1,3 \%$.

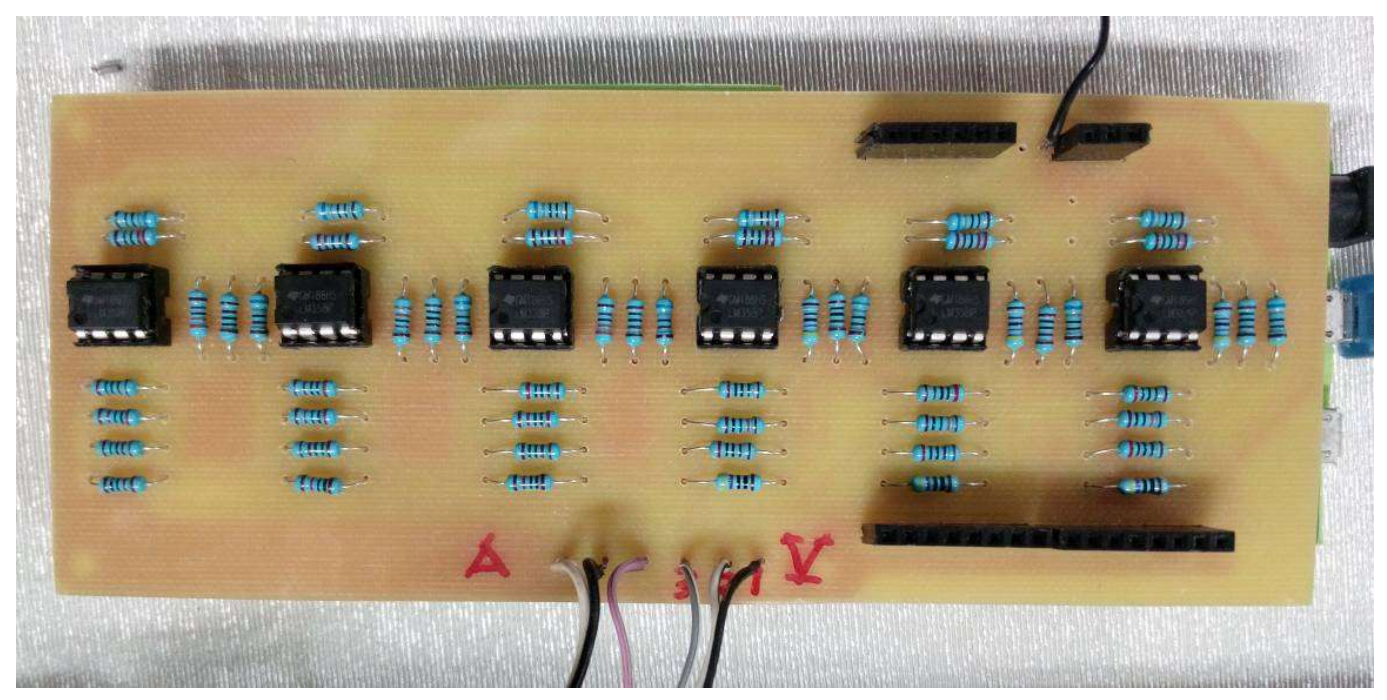

Gambar 3. Rangkaian Pengondisi Sinyal Tegangan dan Arus

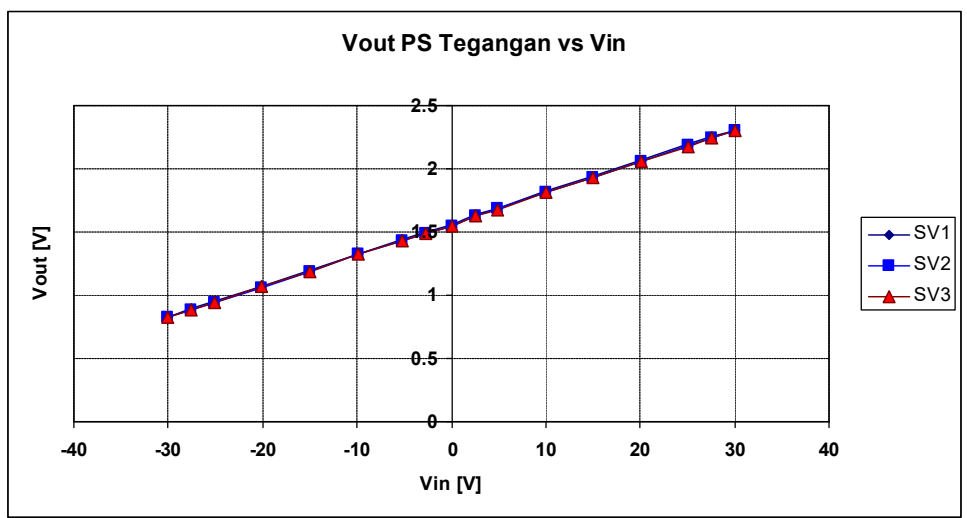

(a)

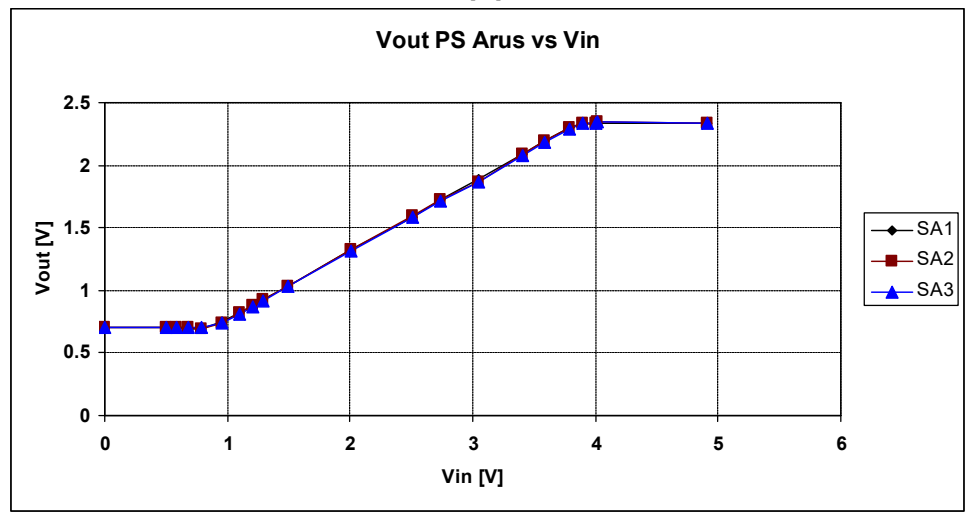

(b)

Gambar 4. Kurva Karakteristik Pengondisi Sinyal Tegangan (a) dan Arus (b) 
Untuk pengondisi sinyal pengukur arus, tegangan masukan diberikan bervariasi dari OV sampai 5V, diperoleh hasil kurva karakteristik seperti ditunjukkan oleh Gambar 4b. Diambil daerah yang linear yaitu untuk tegangan masukan $0,9 \mathrm{~V}$ hingga 3,8V. Kesalahan sensitifitas terhadap nilai perancangan berdasarkan Persamaan (4) diperoleh sebesar 1,9\% dan kesalahan nilai ofset sebesar $17 \%$.

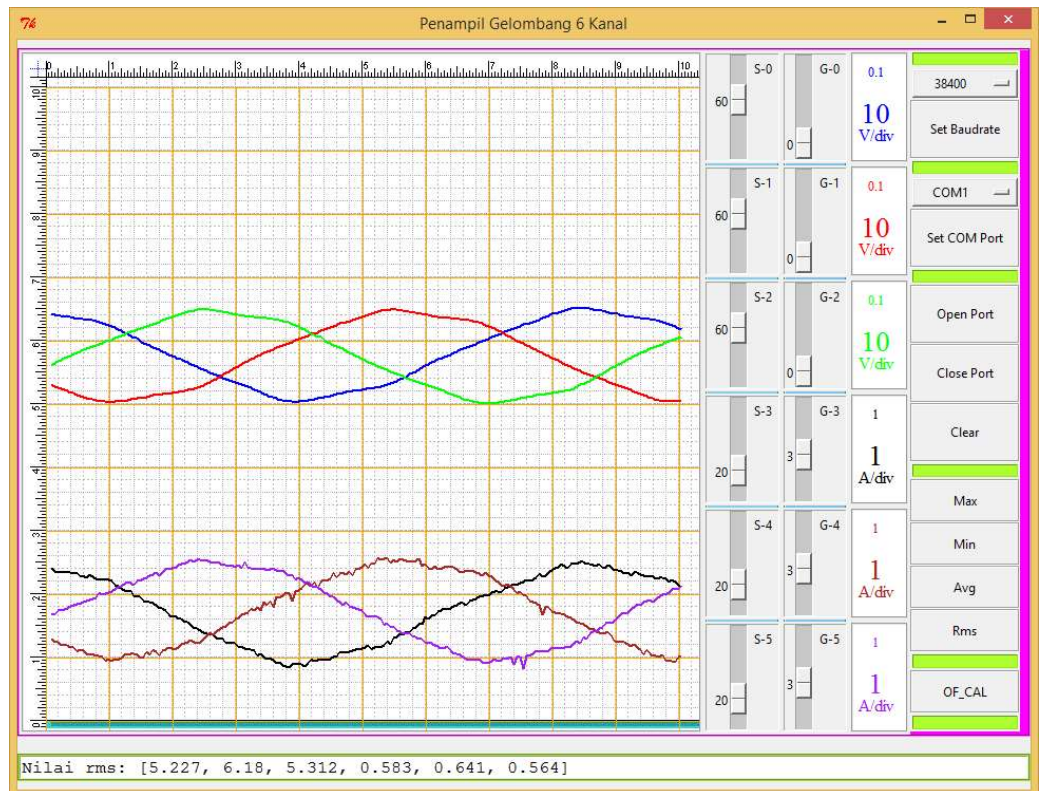

(a)

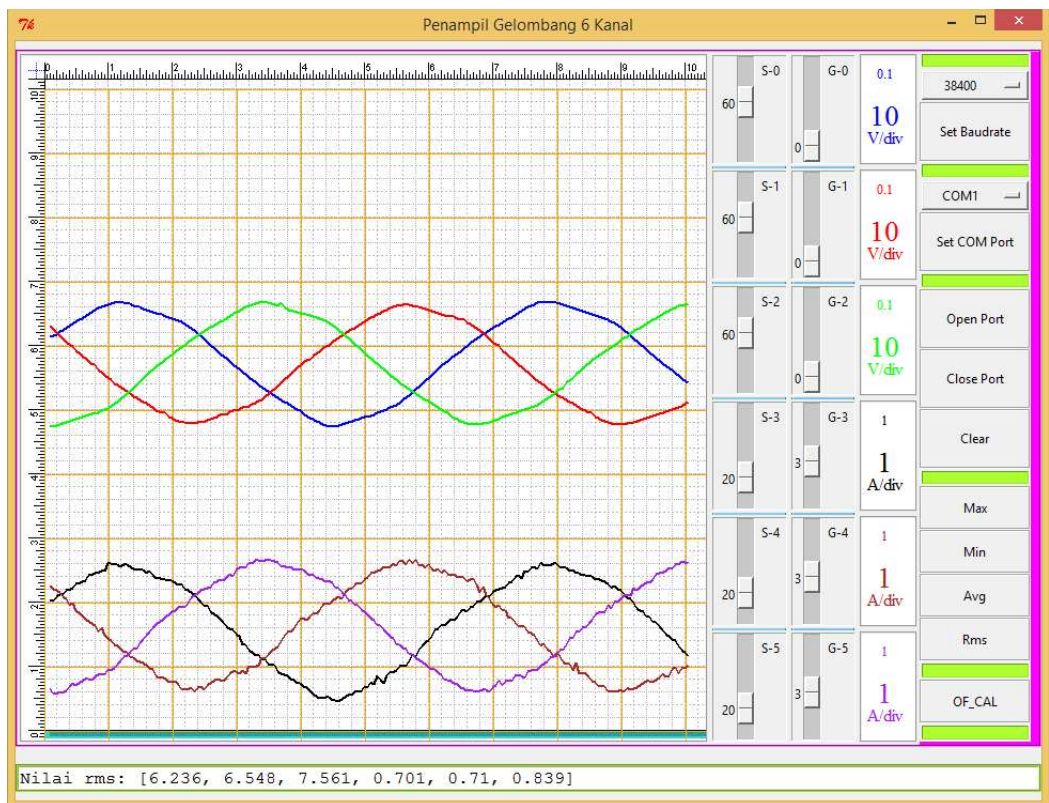

(b)

Gambar 5. Tampilan GUI Saat Pengukuran Tegangan dan Arus

Penerapan untuk pengukuran gelombang keluaran generator tiga fasa telah dilakukan. Gambar 5 menunjukkan tampilan GUI saat dilakukan pengukuran untuk dua kondisi putaran poros yang berbeda, Gambar 5(a) untuk putaran 77rpm, dan Gambar (b) untuk 100rpm. Saat 
pengukuran generator diberi beban hambatan 9 ohm pada setiap fasa. Tegangan rms untuk Gambar 5(a) berturut-turut: 5,227V, 6,180V dan 5,312V, dengan arus sebesar: 0,583A, 0,641A, dan 0,564A. Tegangan rms untuk Gambar 5(b) berturut-turut: 6,236V, 6,548V, dan 7,561V, dengan arus sebesar: 0,701A, 0,71A, dan 0,839A.

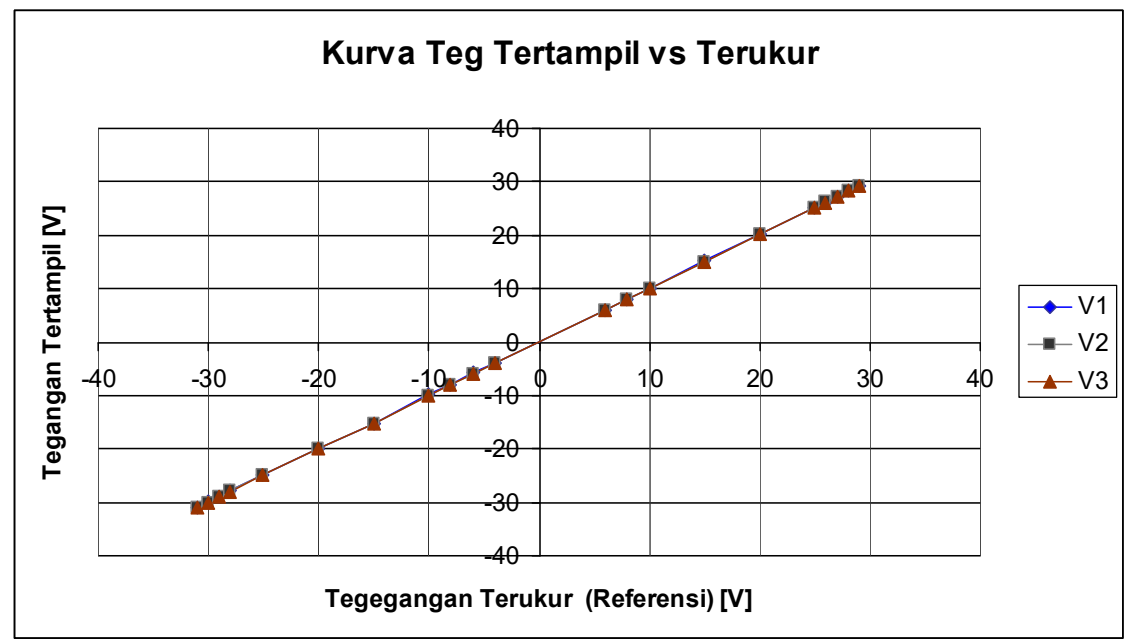

(a)

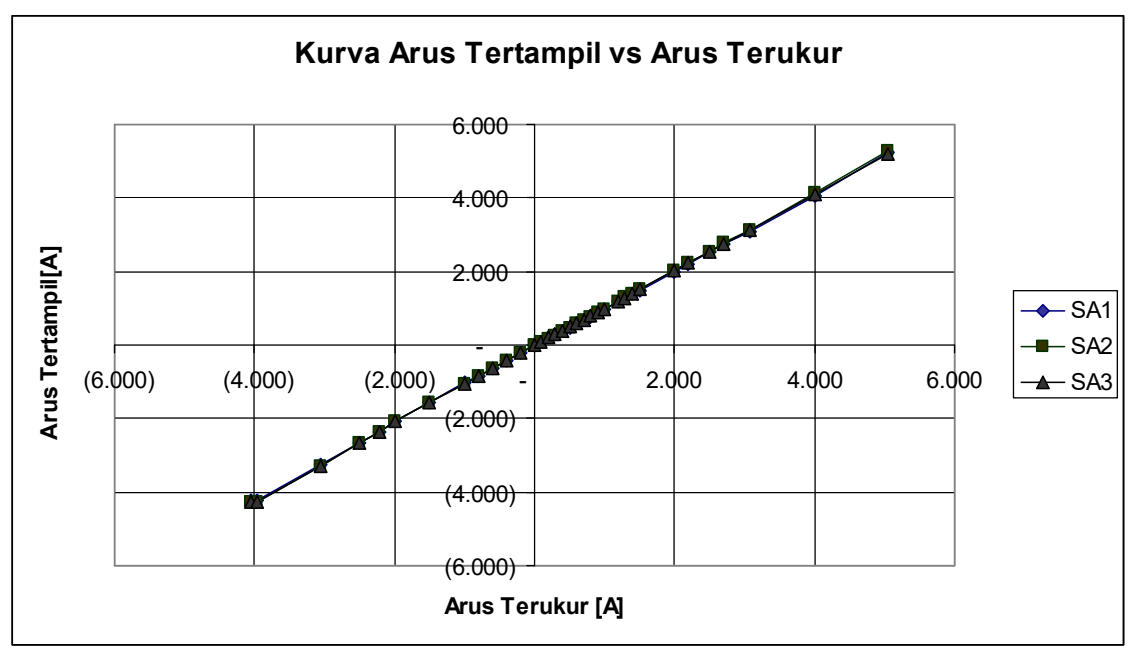

(b)

\section{Gambar 6. Kurva Karakteristik Sistem Penampil Tegangan (a) dan Arus (b)}

Pengujian sistem telah dilakukan secara terpisah untuk pengukuran tegangan dan arus. Sebagai acuan pengukuran tegangan dan arus digunakan multimeter SANWA PC510. Pengukuran tegangan dilakukan dengan memberikan tegangan yang bervariasi mulai dari 30V sampai $+30 \mathrm{~V}$. Hasil pengujian ditunjukkan oleh Gambar 6(a). Untuk ketiga pengujian diperoleh nilai rata-rata kesalahan sebesar $1 \%$, dengan jangkauan pengukuran dari $-30 \mathrm{~V}$ sampai $+29 \mathrm{~V}$. Untuk pengukuran arus dilakukan untuk mengukur arus beban mulai dari $-5 \mathrm{~A}$ sampai +5A diperoleh hasil kurva karakteristik seperti ditunjukkan oleh Gambar 6(b), kesalahan rata-rata ketiga pengukuran arus sebesar 3,15\%, dengan jangkauan pengukuran dari $-4 \mathrm{~A}$ sampai $+5 \mathrm{~A}$. 


\section{KESIMPULAN}

Berdasar hasil implementasi dan pengujian diperoleh bahwa sistem penampil sudah bisa menampilkan bentuk gelombang keluaran tegangan dan arus sekaligus, menampilkan nilai maksimum, minimum, rerata, dan rms. Jangkauan level tegangan yang bisa ditampilkan adalah mulai dari $-30 \mathrm{~V}$ sampai dengan $+29 \mathrm{~V}$. Jangkauan level arus yang bisa ditampilkan adalah $-4 \mathrm{~A}$ sampai $+5 \mathrm{~A}$. Nilai rata-rata kesalahan untuk ketiga pengukuran tegangan adalah $1 \%$, dan untuk ketiga pengukuran arus: 3,15\%. Kekurangan sistem ini adalah belum adanya pengaturan basis waktu.

\section{UCAPAN TERIMA KASIH}

Penulis mengucapkan terima kasih kepada Direktorat Riset dan Pengabdian Masyarakat, Direktorat Jendral Penguatan Riset dan Pengembangan, Kementrian Riset, Teknologi, dan Pendidikan Tinggi atas hibah Penelitian Terapan Unggulan Perguruan Tinggi tahun 2019 serta kepada LPPM Universitas Sanata Dharma sehingga penelitian ini dapat berlangsung dengan baik.

\section{DAFTAR RUJUKAN}

Abdillah, A.W., Syahrial, Waluyo, (2016), Perancangan Generator Magnet Permanen dengan Arah Fluks Aksial untuk Aplikasi Pembangkit Listrik. Jurnal Reka Elkomika, 4(2):93-108 Allegro, (2019), Fully Integrated, Hall-Effect-Based Linear Current Sensor IC with 2.1 kVRMS Isolation and a Low-Resistance Current Conductor ACS712, Allegro MicroSystems.

Arduino, (2017), Getting started with the Arduino Due, Retrieved from https://www.arduino.cc/en/Guide/ArduinoDue.

Arduino, (2019), Language Reference, Retrieved from https://www.arduino.cc/reference/en/

Carter, B., Brown, T.R., (2016), Handbook of Operational Amplifier Applications, Texas Instruments Incorporated.

Emmanuel, O., (2018), Arduino Based Real-Time Oscilloscope, Retrieved from https://circuitdigest.com/microcontroller-projects/arduino-oscilloscope-code-circuit

Karim, I.A., (2014), A low cost portable oscilloscope based on Arduino and GLCD, International Conference on Informatics, Electronics and Vision, ICIEV 2014.

Kuchling, A.M., (2010), The Python Tutorial, Retrieved from https://docs.python.org/2.7/tutorial/index.html.

Noprizal, L., Syukri, M., Syahrizal. (2016). Perancangan Prototype Generator Magnet Permanen 1 Fasa Jenis Fluks Aksial pada Putaran Rendah. KITEKTRO, 1(1), 40-44

Prasetijo, H., Ropiudin, Dharmawan, B.. (2012). Generator Magnet Permanen Sebagai Pembangkit Listrik Putaran Rendah. Dinamika Rekayasa, 8(2), 70-77 
Martanto, dkk

Texas Instruments, (2019), LMx58-N Low-Power, Dual-Operational Amplifiers, Texas Instruments Incorporated.

Willems, K., (2017), Beginners Guide, Retrieved from https://wiki.python.org/moin/BeginnersGuide. 